\title{
TREE APPRAISAL: CHRONOLOGY OF NORTH AMERICAN INDUSTRY GUIDANCE
}

\section{By Scott Cullen}

\begin{abstract}
Various individual tree appraisal methods emerged during the first half of the 20th century. Development of North American industry consensus methods was undertaken in 1947. These methods have been refined and elaborated, and additional guidance has been provided in subsequent revisions. Appraisers and appraisal users, however, are not always aware of the most current methods and guidance and may, unknowingly, rely on outdated versions. The purpose of this paper is to provide an accurate and quick reference to the chronology of North American industrywide consensus methods and guidance for tree and plant appraisal. The differences among methods, guidance, and standards are also explained.

Key Words. Appraisal; appraisal guides; tree appraisal; valuation.
\end{abstract}

\section{INTRODUCTION \\ Background}

It is often necessary in arboriculture and urban forestry to appraise, that is to place a monetary value on, trees or other plants. Various methods have been developed in North America and elsewhere (see, for example, Watson 2002). Tree and plant appraisers can be arborists, foresters, horticulturists, landscape architects, nurserymen, or other professionals (Abbott 1976; Flook 1996, p. 53; Standards Australia 1999, §1.2; CTLA 2000a, p. 115). In fact, plant appraisers are qualified by various combinations of education, training, knowledge, skill, experience, and judgment (CTLA 2000a, p. 115) rather than any particular background or affiliation. These appraisers are often called "experts," and the methods they use are often called "expert methods" (e.g., Lorenzo et al. 2003; Price 2003). They are considered "experts" when they provide opinions in court proceedings (e.g., GPO 2004; DCA 2005). Tree and plant appraisers are unlikely to have a formal background in appraisal or valuation and, in any case, rely on published methods, guidance or standards. Methods and associated guidance, based on industry consensus, have been widely used in North America over the years. They have often been considered the "generally accepted" guidance, a term of art describing the "Frye" test of the admissibility of scientific or technical evidence by "experts" in many U.S. courts (see, for example, Berger 2000). They are sometimes described as "standard," but in fact have never been promulgated as standards. As shown in Table 2 later in this paper, each version of the primary guidance since 1975 has explicitly been titled "guide." This has been reinforced by commentators. Tate (1989), for example, noted that "the guide is a guide, no more, no less." Similar statements are found in the guidance itself (CTLA 1992, p. vi; CTLA 2000a, p. xiv).

\section{Need and Purpose}

The courts, the insurance industry, regulatory agencies, resource managers, and other decision makers rely on appraisals and accept the representations of tree and plant appraisers in good faith. Some "expert" appraisers, however, are not aware of the most current methods and guidance and unknowingly use outdated versions. Available, thirdparty guidance may refer readers to outdated versions or describe outdated methods (e.g., Kuhns 2003; van der Hoeven, no date). If an older version is represented as "current," either explicitly or implicitly, when in fact it is not, the appraisal results may be misleading or inaccurate. This is especially true if the outdated guidance includes outdated cost data. Outdated versions are also likely to fail a "general acceptance" test.

Professional appraisers have a duty to present appraisals in a manner that is not misleading (RICS 2003; IVSC 2005; Appraisal Institute of Canada 2005; Appraisal Standards Board 2005). Members of the American Society of Consulting Arborists have a duty to use "adequate and appropriate" methodology (ASCA 1996, §4.1(C)). ISA Board-Certified Master Arborists have a duty to work in an "accurate ... and complete manner" (ISA 2004, §I(C)(4)). Similar duties may be imposed by other professional organizations. Tree and plant appraisers should be alert to publication of new versions. This should be inherent in maintaining current appraisal competence (CTLA 2000a, p 115).

The principal purpose of this paper is to provide both appraisers and appraisal users with an accurate, complete, and quick reference to the chronology of North American industry consensus guidance (including methods) and supplemental guidance on tree and plant appraisal. This chronology is presented later in this paper in Tables 2 and 3, respectively. The scope of this paper is industry-wide guidance and does not extend to regional guidance.

The older entries in Table 2 will be of more historical than practical concern. A secondary purpose of this paper is to document this history, which may provide useful insights 
into the evolution of methods and guidance. This paper relies on review of the nine published versions rather than inconsistent secondary source references. A brief history is provided as additional background.

Appraisers and appraisal users and commentators may be unclear on the differences among methods, guidance, and standards. Another secondary purpose of this paper is to briefly explain these differences and to define consensus.

\section{A BRIEF HISTORY}

The appraisal or valuation of amenity, landscape, ornamental, or shade trees has been considered in the North American literature since the early 1900s (e.g., Solotaroff 1911, p. 145; Roth 1916, p. 98; Stone 1916; Pack 1922, pp. 231-239; Roth 1925/26). Various individuals developed or compiled methods over the years (e.g., Felt 1938, pp. 3638; Felt 1942, pp. 76-82; McMichael 1951, pp. 383-389; Spicer 1969). The tree care industry started to address the idea of a sound consensus method in 1947 at the 23rd National Shade Tree Conference (Armstrong 1947). At that time, a joint committee of the National Shade Tree Conference (now called the International Society of Arboriculture) and the National Arborist Association (now called the Tree Care Industry Association) was formed to devise a shade tree valuation method. Their initial work was presented in basic form in 1951 at the 27th National Shade Tree Conference (NSTC/NAA 1957; Tilford 1965; Lewis 1970). After additional work, the first industry consensus method was published in 1957 (NSTC/NAA 1957; Tilford 1965; Lewis 1970). Subsequently, methods have been added, refined, and elaborated, and additional guidance has been provided in various revisions. Experience has always led to suggestions for such improvement (e.g., Kielbaso 1971, 1975, 1979; Chadwick 1975; Rey-Lescure 1985; Tate 1989).

The American Society of Consulting Arborists and the American Association of Nurserymen (now called the American Nursery and Landscape Association) joined the effort in 1973 (Neely 1975, pp. 1-2). The scope of guidance was broadened in a 1975 revision to include other plants in addition to trees (Neely 1975, p. 1). The Council of Tree and Landscape Appraisers (CTLA) was established in 1975 (Davis 1983; CTLA 1992, p. v), effectively making this a "green" rather than tree industry effort (CTLA 1986, p. 2). As shown in Table 1, CTLA has continued to expand its constituency (CTLA 2000a, p. xiii).

Nine versions of industry consensus guidance have been published from 1957 to 2000 (Table 2). CTLA is preparing a 10th edition (Ingram 2004). Separate, supplemental guidance has also been published from time to time (Table 3). Over the years, various regional industry groups, now known as Regional Plant Appraisal Committees (CTLA 2000, pp. 58-60), have published supplemental regional guidance which is beyond the scope of this paper.

\section{METHODS, GUIDANCE, AND STANDARDS}

Methods, guidance, and standards can be characterized and distinguished in a number of ways:

- by their content,

- by who develops them, and

- by their authority or strength.

\section{Methods}

An appraisal method is a "specific process or way to estimate value" or to "develop an opinion of value" and may include various steps, procedures, or techniques (Appraisal Standards Board 2003; IVSC 2005, GN5 \$3.21-22). Appraisal methods usually involve specific calculations. Methods may be developed by individuals (e.g., Felt 1942; Helliwell 1967; Raad 1976; Flook 1996; Thyer 1999; Helliwell 2003), single organizations (e.g., AEPJP 1999), or by broader consensus (e.g., NSTC/NAA 1957; VVOG 1979; Randrup et al. 2003). Methods do not have authority in and of themselves but may gain authority by force of law or agreement, by general acceptance, or by inclusion in a standard.

\section{Guidance}

Guidance may be simply a statement of method(s) (e.g., Helliwell 2003), separate explanation or advice (e.g., CTLA 1986), or a combination of both (e.g., CTLA 2000a). Guidance also may be developed by individuals, by single

Table 1. Council of Tree and Landscape Appraisers (CTLA).

\begin{tabular}{|c|c|}
\hline Constituent organization & Year joined \\
\hline $\begin{array}{l}\text { American Nursery and Landscape Association (ANLA) } \\
\text { formerly American Association of Nurserymen (AAN) }\end{array}$ & $1975^{2}$ \\
\hline American Society of Consulting Arborists (ASCA) & $1975^{2}$ \\
\hline $\begin{array}{l}\text { International Society of Arboriculture (ISA) } \\
\text { formerly International Shade Tree Conference (ISTC) } \\
\text { formerly National Shade Tree Conference (NSTC) }\end{array}$ & $1975^{2}$ \\
\hline $\begin{array}{l}\text { Professional Landcare Network (PLANET) } \\
\quad \text { formerly Associated Landscape Contractors of America (ALCA) }\end{array}$ & $1975^{z, y}$ \\
\hline $\begin{array}{l}\text { Tree Care Industry Association (TCIA) } \\
\quad \text { formerly National Arborist Association (NAA) }\end{array}$ & $1975^{2}$ \\
\hline Association of Consulting Foresters of America (ACF) & $1996^{x}$ \\
\hline American Society of Landscape Architects (ASLA) & $1997^{\mathrm{x}}$ \\
\hline
\end{tabular}


Table 2. Chronology of industry consensus guidance on tree and plant appraisal.

\begin{tabular}{ll}
\hline Title & Author/year \\
\hline $\begin{array}{l}\text { Shade Tree Evaluation } \\
\text { Shade Tree Evaluation, Revision I }\end{array}$ & (NSTC/NAA 1957) \\
Shade Tree Evaluation, Revision II & (Tilford 1965) \\
$\begin{array}{l}\text { Guide to the Professional Evaluation of Landscape } \\
\text { Trees, Specimen Shrubs and Evergreens, } \\
\text { Revision III }\end{array}$ & (Lewis 1970) \\
$\begin{array}{l}\text { Guide for Establishing Values of Trees and Other } \\
\text { Plants, Revision IV }\end{array}$ & (Neely 1975) \\
$\begin{array}{l}\text { Guide for Establishing Values of Trees and Other } \\
\text { Plants (6th ed.) }\end{array}$ & (Neely 1979) \\
Valuation of Landscape Trees, Shrubs, and Other \\
$\begin{array}{l}\text { Plants: A Guide to the Methods and Procedures } \\
\text { for Appraising Amenity Plants (7th ed.) }\end{array}$ \\
$\begin{array}{l}\text { Guide for Plant Appraisal (8th ed.) } \\
\text { Guide for Plant Appraisal (9th ed.) }\end{array}$
\end{tabular}

Table 3. Chronology of supplemental industry guidance on tree and plant appraisal. ${ }^{z}$

\begin{tabular}{ll}
\hline Title & Author/year \\
\hline Manual for Plant Appraisers (1st ed.) & (CTLA 1986) \\
Workbook_Guide for Plant Appraisal (8th ed.) & (CTLA 1993) \\
Field Report Guide for Trunk Formula (8th ed.) & (CTLA 1995) \\
Field Report Guide for Cost of Cure (8th ed.) & (CTLA 1997) \\
$\begin{array}{l}\text { Field Report Guide for Trunk Formula and Replacement } \\
\text { Cost Methods (9th ed.) }\end{array}$ & (CTLA 2000b) \\
Workbook_Guide for Plant Appraisal (9th ed.) & (CTLA 2000c) \\
\hline
\end{tabular}

${ }^{2}$ Table 3 is limited to industry-wide or national, supplemental guidance. Regional supplemental guidance is beyond the scope of this paper. yote that the 1986 manual was intended as a companion handbook and was not an edition or revision of the consensus guidance listed in Table 2. This additional material was incorporated into a single publication from the 1992 8th edition onward (CTLA 1992, p. vi).

organizations, or by broader consensus. Guidance may gain authority by force of law or agreement or by general acceptance. Even with such authority, guidance may allow more discretion or latitude than standards.

\section{Standards}

Standards are statements of requirements for behavior or performance or for design. They may also include methods and additional guidance. Standards are seldom if ever developed by individuals. They may be developed by single organizations (e.g., ASCA 1996; RICS 2003) or government (NIST 2005) but more often by broader consensus. "Con- sensus bodies" include representatives from "materially affected and interested parties" (ANSI 2005) or "stakeholders" (CEN 2005; ISO 2005; Standards Council of Canada 2005) including businesses, industry, trade, government, academia, the scientific community, consumers (BSI 2005; DIN 2005), or "others with relevant knowledge" (ISO 2005). Readers may be most familiar with national, consensus performance standards for tree care (e.g., BSI 1989; ANSI 1994; Standards Australia 1996; ANSI 2001) or related fields (e.g., ANSI 2004). Standards are often stated as binding but may be limited to guidance (e.g., Standards Australia 1999). Barrell (1995), as another example, notes that the British Standard 5837 (BSI 1991) "is more of a guidance reference than an absolute set of rules." Standards gain their actual authority by force of law or agreement, by voluntary compliance, or by general acceptance. When guidance, advice, or clarification are included in standards, they may be as binding as the standards themselves (e.g., Appraisal Standards Board 2005, Statements; IVSC 2005, Guidance Notes) or may be supplemental (e.g., Appraisal Institute of Canada 2005, Practice Notes; Appraisal Standards Board 2005, Advisory Opinions). Even when not strictly binding (e.g., RICS 2003, Guidance Notes), supplemental guidance may be considered to be "best practice" or to define a "standard of care."

\section{DISCUSSION}

As already noted, North American industry consensus guidance on tree and plant appraisal has not been promulgated as standard. Particular laws, regulations, or agreements may, however, require its use. Otherwise, other local or national methods may properly be used (ASCA 1996, §4.1(C)). Increasing international awareness, for example, may lead North American plant appraisers to other useful methods such as those described by Watson (2002). When consensus guidance is used, however, it is usually appropriate to rely on the most current version.

There are situations when it is not strictly necessary to use the most current methods or guidance. In retrospective cases, for example, it is often appropriate to use the methods or guidance that would have been current at some earlier date. Appraisers may intentionally use older methods, techniques, or guidance, in whole or in part, if more suitable for a particular appraisal problem. There may be transition periods when either the most current version or its immediate predecessor is appropriate. Exceptions or departures from the most current methods or guidance generally should be disclosed in any appraisal report. 


\section{SUMMARY}

North American tree and plant appraisers rely on greenindustry consensus guidance-including methods-that has evolved through nine published versions from 1957 to 2000. A 10th edition of the CTLA guide is in preparation. This industry consensus guidance is not promulgated as a standard but is generally accepted in North America. Plant appraisers will be most credible if they use appropriately current methods and guidance. They should be alert to publication of new versions. This should be inherent in maintaining current appraisal competence. Appraisal users will benefit by confirming that appraisal opinions have been developed using appropriately current methods and guidance.

\section{LITERATURE CITED}

Abbott, Richard. 1976. Arboricultural and Horticultural Appraisal. The Arboriculturist (Davey Tree) 1(3):1-12.

American National Standards Institute (ANSI). 1994. American National Standard for Tree Care OperationsPruning, Trimming, Repairing, Maintaining and Removing Trees, and Cutting Brush—Safety Requirements. ANSI Z133.1-1994. International Society of Arboriculture, Champaign, IL.

- 2001. American National Standard for Tree Care Operations-Tree, Shrub and Other Woody Plant Maintenance-Standard Practices, Pruning. ANSI A300 Part 1-2001. Tree Care Industry Association, Manchester, $\mathrm{NH}$.

\section{- 2004. ANSI Z60.1-2004 American Standard for} Nursery Stock. American Nursery \& Landscape Association, Washington, DC.

- 2005. American National Standards Institute Web site. www.ansi.org (accessed 5/16/05).

American Society of Consulting Arborists (ASCA). 1996. Standards of Professional Practice. American Society of Consulting Arborists, Rockville, MD. 24 pp.

Appraisal Institute of Canada. 2005. Canadian Uniform Standards of Professional Appraisal Practice (USPAP). Appraisal Institute of Canada, Ottawa, ON. 35 pp.

Appraisal Standards Board. 2005. Uniform Standards of Professional Appraisal Practice (USPAP). The Appraisal Foundation, Washington, DC.

— . 2003. Glossary in Uniform Standards of Professional Appraisal Practice (USPAP). The Appraisal Foundation, Washington, DC.

Armstrong, N. 1947. Shade tree evaluation formulas and their use, pp. 38-48. In Proceedings of the 23rd National Shade Tree Conference, 18-22 Aug. 1947, Cleveland, OH.

Asociación Española de Parques y Jardines Públicos (AEPJP). 1999. Método para valoración de árboles y arbustos ornamentales. 1999 Neuva Norma Granada. Asociación
Española de Parques y Jardines Públicos, Madrid, Spain. $71 \mathrm{pp}$.

Barrell, Jeremy. 1995. SULE: The cutting edge in predevelopment tree assessment methodology, pp. 143-155. In Watson, Gary W., and Dan Neely (Eds.). Trees and Building Sites: Proceedings of an International Workshop on Trees and Buildings. International Society of Arboriculture, Champaign IL. 191 pp.

Berger, Margaret. 2000. The Supreme Court's trilogy on the admissibility of expert testimony, pp. 9-38. In Reference Manual on Scientific Evidence (2nd ed.). Federal Judicial Center, Washington, DC. www.fjc.gov (accessed 5/16/05).

British Standards Institution (BSI). 1989. Recommendations for Tree Work. BS 3998. British Standards Institution, London, UK. . 1991. Guide for Trees in Relation to Construction. BS 5837. British Standards Institution, Milton Keynes, England.

_ 2005. BSI Global Web site. www.bsi-global.com (accessed 5/16/05).

Chadwick, L.C. 1975. ASCA recommendations for modification of the ISTC Shade Tree Evaluation Formula. J. Arboric. 1(2):35-38.

Comité Europeén de Normalisation-European Committee for Standardization (CEN). 2005. European Committee for Standardization Web site. www.cenorm.be (accessed 5/16/05).

Council of Tree and Landscape Appraisers (CTLA). 1986. Manual for Plant Appraisers: A Handbook of Methods, Procedures and Problems of Plant Appraisal (1st ed.). Council of Tree and Landscape Appraisers, Washington, DC. 57 pp.

. 1992. Guide for Plant Appraisal (8th ed.). International Society of Arboriculture, Champaign, IL. $103 \mathrm{pp}$.

—_. 1993. Workbook—Guide for Plant Appraisal (8th ed.) International Society of Arboriculture, Champaign, IL. 12 pp.

— 1995. Field Report Guide for Trunk Formula (8th ed.). Council of Tree and Landscape Appraisers, Washington, DC. 4 pp.

_ 1997. Field Report Guide for Cost of Cure (8th ed.). International Society of Arboriculture, Champaign, IL. 9pp.

— . 2000a. Guide for Plant Appraisal (9th ed.).

International Society of Arboriculture, Champaign, IL. $143 \mathrm{pp}$.

- 2000b. Field Report Guide for Trunk Formula and Replacement Cost Methods (9th ed.). Council of Tree and Landscape Appraisers, Washington, DC.

_ 2000c. Workbook—Guide for Plant Appraisal (9th ed.). International Society of Arboriculture, Champaign, IL. 12 pp. 
Davis, S.H. 1983. Tree valuation pitfalls. J. Arboric. 9(6):164-166.

Department for Constitutional Affairs (DCA). 2005. Rule

35.2 in Civil Procedure Rules. Secretary of State for

Constitutional Affairs, London, UK. www.dca.gov.uk/civil/ procrules_fin/index.htm (accessed 5/16/05).

Deutsches Institut für Normung (DIN). 2005. Deutsches Institut für Normung Web site. www2.din.de (accessed 5/16/05)

Felt, E.P. 1938. Our Shade Trees. Orange Judd Publishing, New York, NY. 187 pp.

—. 1942. Our Shade Trees (2nd ed.). Orange Judd Publishing, New York, NY. 187 pp.

Flook, Ron. 1996. STEM: A Standard Tree Evaluation Method. Ron Flook, Nelson, NZ. 75 pp.

Government Printing Office (GPO). 2004. Rule 702, Testimony by Experts, in Federal Rules of Evidence. U.S. Government Printing Office, Washington, DC.

Ingram, James. 2004. Open Forum on Suggestions for 10th Edition, at the American Society of Consulting Arborists Annual Conference, 2 Dec. 2004, Philadelphia, PA.

International Society of Arboriculture (ISA). 2004. ISA BoardCertified Master Arborist Code of Ethics, in ISA BoardCertified Master Arborist Application Booklet. International Society of Arboriculture, Champaign, IL. 27 pp.

Helliwell, D.R. 1967. The amenity value of trees and woodlands. Arboric. J. (1):128-131.

- 2003. Visual Amenity Valuation of Trees and Woodlands (The Helliwell System) (3rd. ed.). Arboricultural Association Guidance Note 4. The Arboricultural Association, Romsey, Hampshire, UK.

International Standards Organization (ISO). 2005. International Standards Organization Web site. www.iso.org (accessed 5/16/05).

Kielbaso, J. James. 1971. Economic values of trees in the urban locale, pp. 82-94. In Proceedings of Symposium on the Role of Trees in the South's Urban Environment, 3 Feb. 1971. University of Georgia, Athens, GA.

- 1975. Should hardiness zones and location be a part of the ISTC shade tree evaluation formula? J. Arboric. 1(5):93-97.

_ 1979. Evaluation of trees in urban areas. J. Arboric. 5:70-72.

Kuhns, Michael. 2003. Species Ratings for Landscape Tree Appraisal in Utah. Utah State University Forestry Extension, Logan, UT. http://extension.usu.edu/forestry/ Reading/Assets/PDFDocs/NR_FF/NRFF001.pdf (accessed 5/16/05).

Lewis, Clarence E. (Ed.). 1970 Shade Tree Evaluation, Revision II. International Shade Tree Conference, Urbana, IL. 44 pp.

Lorenzo, Alfredo B., Catalino A. Blanche, and James F. Henson. 2003. Concordance among extension workers, researchers, and professional arborists in rating landscape trees. Journal of Extension [online] 41(5) (October). www.joe.org/joe/ 2003october/rb2.shtml (accessed 5/16/05).

McMichael, Stanley L. 1951. What are trees worth? Chapter 15, pp. 383-393. In McMichael's Appraising Manual (4th ed.) Prentice-Hall, New York, NY.

National Shade Tree Conference/National Arborist Association (NSTC/NAA). 1957. Shade Tree Evaluation. National Shade Tree Conference, Columbus, $\mathrm{OH}$, and National Arborist Association, Wooster, OH. Published at Wooster, OH. 14 pp.

Neely, Dan (Ed.). 1975. A Guide to the Professional Evaluation of Landscape Trees, Specimen Shrubs, and Evergreens, Revision III. International Society of Arboriculture, Champaign, IL. 18 pp.

- 1979. Guide for Establishing Values of Trees and Other Plants, Revision IV. International Society of Arboriculture, Champaign, IL. 42 pp.

- 1983. Guide for Establishing Values of Trees and Other Plants (6th ed.). International Society of Arboriculture, Champaign, IL. 48 pp.

- 1988. Valuation of Landscape Trees, Shrubs, and other Plants: A Guide to the Methods and Procedures for Appraising Amenity Plants (7th ed.). International Society of Arboriculture, Champaign, IL. 50 pp.

National Institute of Standards and Technology (NIST). 2005. National Institute of Standards and Technology Web site. www.nist.gov (accessed 5/17/05).

Pack, Charles Lathrop. 1922. Legal values of shade trees, Chapter XXI. In Trees As Good Citizens. The American Tree Association, Washington, DC.

Price, Colin. 2003. Quantifying the aesthetic benefits of urban forestry. Urban For. Urban Green. 2(1):123-133.

Professional Landcare Network (PLANET). 2005. Professional Landcare Network Web site. www.alca.org (accessed 5/17/05).

Raad, A. 1976. Trees in towns and their evaluation. Arboric. J. 3(1):2-26.

Randrup, T.B., L. Poulsen, and S. Holgersen. 2003. VAT 03Værdisætning af Træer [Valuation of Trees]. Forlaget Grønt Miljø, Copenhagen. 32 pp. [In Danish].

Rey-Lescure, E. 1985. The location factor and replacement value. J. Arboric. 11(5):132-136.

Royal Institution of Chartered Surveyors (RICS). 2003. RICS Appraisal and Valuation Standards (Red Book) (5th ed.). RICS Books, Coventry, UK.

Roth, Filibert. 1916. Forest Valuation: Michigan Manual of Forestry, Vol. II (1st ed.). Filibert Roth, Ann Arbor, MI. 171 pp. http://chla.library.cornell.edu/c/chla/browse/title/ 2864416.html (accessed 5/18/05).

_. 1925/26. Forest Valuation: Michigan Manual of Forestry, Vol. II (2nd ed., rev.). George Wahr, Ann Arbor, MI. 
Solotaroff, William. 1911. Shade Trees in Towns and Cities (1st ed.) John Wiley, New York, NY. 287 pp.

Spicer, O.W. 1969. Appraising Shade and Ornamental Trees. Bartlett Tree Experts, Stamford, CT. 13 pp.

Standards Australia. 1996. Pruning of Amenity Trees. AS 4373-1996. Standards Australia, Sydney, Australia. 10 pp. - 1999. Amenity Trees—Guide to Valuation (Draft). DR 99307. Standards Australia, Sydney, Australia. 19 pp. Standards Council of Canada. 2005. Standards Council of Canada Web site. www.scc.ca (accessed 5/17/05).

Stone, George E. 1916. Valuation of shade trees, pp. 255258. In Shade Trees: Characteristics, Adaptation, Diseases and Care. Bulletin No. 170, Massachusetts Agricultural Experiment Station, Amherst, MA.

Tate, Robert. 1989. ISA tree valuation guide: A critical examination. J. Arboric. 15(6):145-149.

Thyer, Peter, 1999. The Thyer Tree Valuation Method. Peter Thyer, NSW, Australia. www.intercoast.com.au/ thyer-p/ treeval.html (accessed 5/17/05).

Tilford, Paul E. (Ed.). 1965. Shade Tree Evaluation, Revision I. International Shade Tree Conference, Columbus, $\mathrm{OH}$. $29 \mathrm{pp}$.

van der Hoeven, Guido. No date. After the Storm: What is a Tree Worth? NC State University, Raleigh, NC. www.agecon.ncsu.edu/faculty/vanderhoeven/TREELOSS.PDF (accessed 5/17/05).

Vereniging Voor Openbaar Groen (VVOG) (Flemish Federation of Park and Recreation Administration). 1979. Uniforme Methode Voor Waardebepaling Van Straat-, Laan- En Parkbomen Behorend Tot Het Openbaar Domein. Vereniging Voor Openbaar Groen, Brugge, Belgium.

Watson, Gary. 2002. Comparing formula methods of tree appraisal. J. Arboric. 28(1):11-18.

Acknowledgments. Thanks to Lew Bloch, Potomac, Maryland; Peggy Currid and Sharon Lilly of ISA; Dr. Bruce Fraedrich of the Bartlett Tree Research Laboratory; the Mertz Library of the New York Botanical Garden; Fred Micha, Ontario, New York; and Professor Dennis Ryan of the University of Massachusetts-Amherst for their gracious assistance in assembling accurate bibliographic information and historical documents. Insightful suggestions by Journal of Arboriculture Editor Dr. Robert Miller brought clarity to the paper.
Registered Consulting Arborist

P. O. Box 31152

Greenwich, CT 06831, U.S.

dscottcul@att.net

Résumé. Des méthodes diverses d'évaluation monétaire des arbres ont émergé au cours de la première moitié du $20^{e}$ siècle. Le développement de méthodes faisant consensus au sein de l'industrie nord-américaine s'est réalisé en 1947. Ces méthodes ont depuis été raffinées et élaborés, et des conseils additionnels ont été fournies lors de révisions subséquentes. Néanmoins, les évaluateurs et les utilisateurs d'évaluations ne sont pas toujours au courant de la plupart des méthodes et des conseils courants; ils peuvent donc de ce fait sans le savoir se fier à des versions dépassées. Le but de cet article est de fournir une référence chronologique précise et rapide des méthodes et des conseils consensuels au sein de l'industrie nordaméricaine pour l'évaluation des arbres et autres végétaux. Les différences parmi les méthodes, les conseils et les normes sont aussi expliquées.

Zusammenfassung. Verschiedene individuelle Baumuntersuchungsmethoden sind in der ersten Hälfte des 20. Jahrhunderts aufgetreten. 1947 wurde die Entwicklung von Methoden im Konsens mit der nordamerikanischen Industrie begonnen. Diese Methoden wurden verbessert und überarbeitet und zusätzliche Richtlinien wurden in Revisionen geliefert. Die Gutachter und Anwender sind dennoch nicht immer informiert über die neusten Methoden und Richtlinien und vertrauen unwissend auf abgelaufene Versionen. Die Absicht dieser Studie ist es, eine schnelle und akkurate Referenz zur Chronologie der nordamerikanischen industrie-konsenten Methoden und Richtlinien der Baumbewertung zu liefern. Die Unterschiede zwischen den Methoden, Richtlinien und Standards wird auch erklärt.

Resumen. Durante la primera mitad del siglo 20 emergieron varios métodos de evaluación de árboles individuales. El desarrollo de la industria en Norte América condensó métodos que fueron desarrollados desde 1947. Estos métodos han sido refinados y elaborados, y guías adicionales han sido probadas en revisiones subsecuentes. Sin embargo, los usuarios de los métodos y las valoraciones no siempre han estado alertas de los métodos más actuales y pudo ser, tal vez por desconocimiento, que se trabajara con versiones atrasadas. El propósito de este reporte es proporcionar una referencia rápida y precisa, en la cronología de la industria de Norte América, sobre los métodos y guías para la evaluación de árboles y plantas. Se explican las diferencias entre métodos, guías y estándares. 